\title{
Exploring Roman ritual behaviours through plant remains from Pannonia Inferior
}

\author{
Kelly Reed ${ }^{1 *}$, Lisa Lodwick ${ }^{2}$, Tino Leleković ${ }^{3}$ and Hrvoje Vulić ${ }^{4}$ \\ ${ }^{1}$ School of Life Sciences, University of Warwick, Coventry, UK. (kellyreed@hotmail.co.uk) \\ ${ }^{2}$ School of Archaeology, University of Oxford,Oxford, UK (lisa.lodwick@all.souls.ox.ac.uk) \\ ${ }^{3}$ Croatian Academy of Sciences and Arts, Zagreb, Croatia. \\ ${ }^{4}$ Gradski Muzej Vinkovci, Vinkovci, Croatia
}

\begin{abstract}
The recovery of new plant remains from eastern Croatia are discussed here in order to determine their ritual significance and how this evidence may fit into chronological and regional observations on ritual plant offerings in the Roman world. Samples collected from inhumations, cremations and an altar dedicated to Silvanus Domesticus, dating from the 2nd to 4th centuries AD, are presented and show that a range of more 'common' plant remains, such as cereals and pulses, were an important part of ritual life. These results are also compared to the growing archaeobotanical data collected from shrine and cremation burials across Europe. Although the archaeobotanical data from the Croatian sites are limited, the increasing evidence of ritual plant use allows observations regarding the wider context of Roman social and religious change.
\end{abstract}

Keywords: Archaeobotany, Croatia, Cremations, Inhumations, Shrines, Mursa, Cibalae, Roman

\section{Introduction}

The expansion of the Roman Empire into modern day Croatia brought cultural, political, economic and urban planning changes to the newly formed Roman province of Pannonia ca. 14 AD. By 106 $\mathrm{AD}$, around the time of the first and second Dacian wars, Trajan divided the province into Pannonia Superior to the west, with the capital Carnuntum, and Pannonia Inferior to the east, with the capitals in Aquincum and Sirmium (Campbell 2013). As administrative and governmental structures were adopted, adapted and periodically changed from those implemented in Rome, so too were many aspects of Roman religion. Roman life was filled with rituals from the private sphere of the home to the public arena, but how these rituals and religious practices developed in Pannonia within the context of local customs and traditions is still a topic for debate (e.g. Wilkes 1995; Džino 2010, 2012; Džino and Domić-Kunić 2012). Evidence from literature, inscriptions and sculptures emphasises state 
religion and ceremonies (e.g. Fitz 1998), while the excavation of Roman cemeteries have provided a wide range of archaeological information about burial practices in the region (see Leleković 2012 for summary).

Typically, archaeological manifestations of ritual practices are identified through the study of vessels, personal adornments, inscriptions, to name but a few, but very rarely through the recovery of plant and animal remains. Thus, the study of plant offerings is rarely discussed within greater theoretical debates on the nature of ritual behaviour, associated material culture and its significance as social practice. This is in part due to vague literary references on the types of foods selected, how they may have been prepared and their specific role and value within the ritual activity (e.g. Rüpke 2007; Scheid 2007). Plant offerings are seen represented in mosaics, frescoes and sculptures across the empire (e.g. Robinson 2002; Yilmaz et al. 2013), but generally little is known about public or private sacrifice and offerings in colonies or municipia (Scheid 2007, 264). In addition, the study of animal sacrifice, from zooarchaeological, literary and iconographic evidence, has had a greater focus within discussions of ritual behaviour (e.g. King 2005; Morris 2011; Elsner 2012; Scheid 2012; Aldrete 2014), although the importance of plant offerings in Roman religion has been recently highlighted (Schultz 2016).

Within the archaeobotanical community growing evidence has started to emerge over the last decade, mainly from Italy and the western Empire, showing that a range of plants, such as cereals, pulses, fruits and nuts, were used in a variety of rituals (e.g. Bouby and Marinval 2004; Rottoli and Castiglioni 2011). However, in Croatia, archaeobotanical evidence from Roman sites is relatively scarce and so little is known in regards to the role of plants within ritual contexts in the province of Pannonia. Furthermore, the only evidence of archaeobotanical remains within Iron Age ritual contexts is from the early Iron Age Hallstatt necropolis of Kaptol-Gradci (Šoštarić et al. 2017), making comparisons between the periods, in terms of continuity or change, in the use of plants within ritual contexts difficult. This paper therefore presents new archaeobotanical data collected from Roman ritual contexts within Vinkovci (Cibalae) and Osijek (Mursa) (Figure 1), with the aim of determining their ritual significance and how this evidence may fit into chronological and regional observations on ritual plant offerings in the Roman world. 


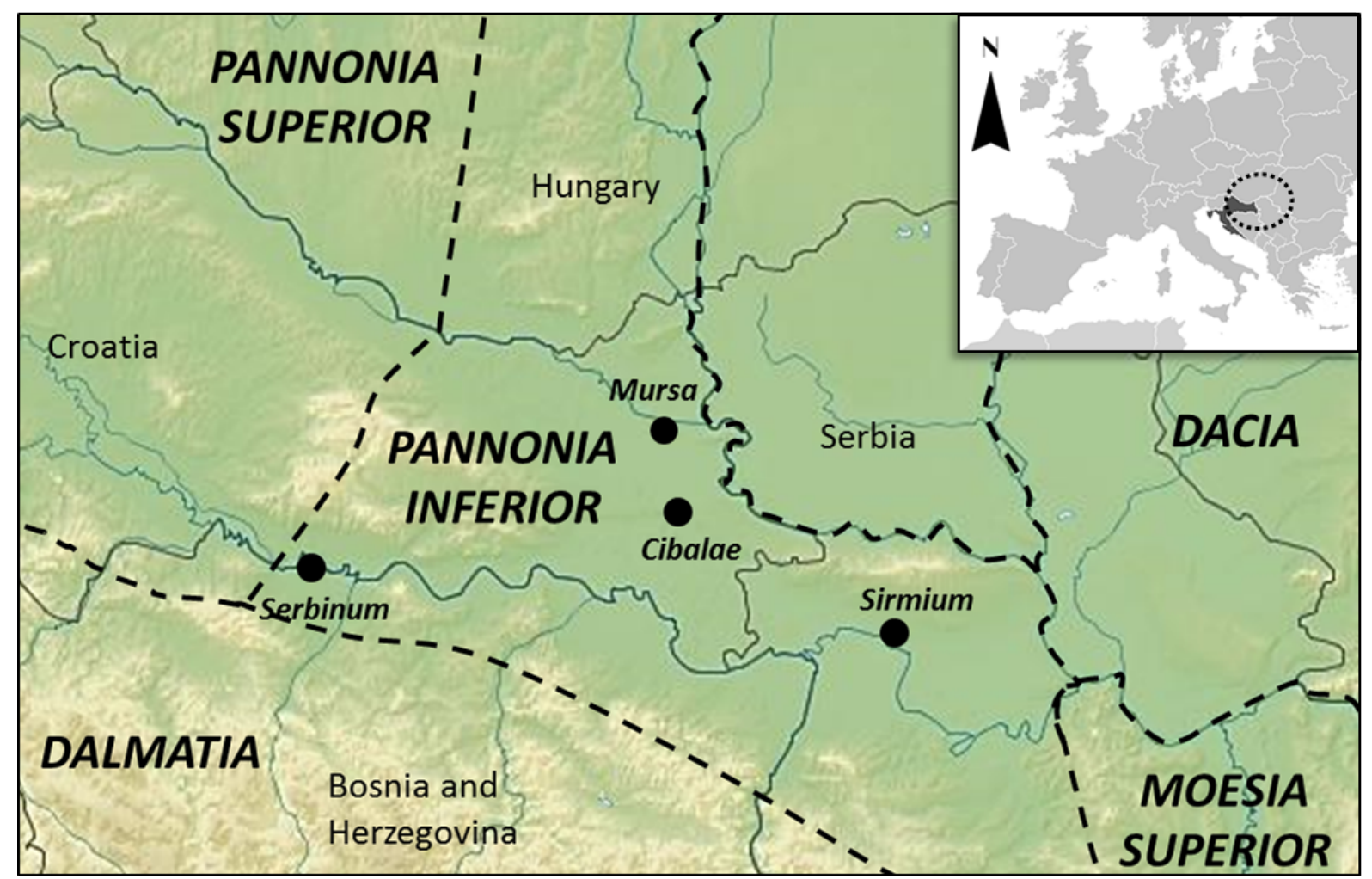

Figure 1. The location of Colonia Aelia Mursa (Osijek) and Cibalae (Vinkovci) within the context of the Roman provinces.

\section{Materials and Methods}

The archaeobotanical material discussed in this paper consists of charred macro-remains from two cremation burials excavated at 120 Divaltova Street (OSDIV94, 123), Osijek, one inhumation from Ulica I. Gundulića 48 (VIG48), Vinkovci, one inhumation and two cremations from Lapovačka ulica Kaufland (VKFL), Vinkovci, and one sample from the remains of an altar at Ulica I. Gundulića 39 (VIG39), Vinkovci, Croatia.

\section{The sites}

Excavations conducted at 120 Divaltova Street (OSDIV), Osijek, revealed 70 inhumation and 12 cremation burials, dating from the $2^{\text {nd }}$ to mid $3^{\text {rd }}$ century $\mathrm{AD}$, located within the southern cemetery. All the cremations appear to be busta or ustrinata graves, containing the pyre debris mixed with the ashes and grave goods (Leleković 2012, 338). Only two cremation graves (Grave 23 and 28) contained identifiable carbonised plant remains out of eleven cremation graves sampled. Grave 23 was an irregular pit $122 \times 44 \mathrm{~cm}$, orientated N-S, containing the cremation and pyre debris along with ceramic dishes and a coin. Grave 28 was a rectangular pit $136 \times 45 \mathrm{~cm}$, orientated E-W, containing with the cremation burial a bronze hair pin, bronze buckle and fragments of ceramic dishes. This cemetery is particularly important as it represents a rare example of the transitional period where two burial rites existed side by side, before the tradition of inhumations became the primary burial custom (Leleković 2012, 332). 
Excavations conducted at Ulica I. Gundulića 48 (VIG48), Vinkovci, revealed five Roman inhumations aligned east west with few grave goods within the western cemetery of Cibalae (Vulić and Rapan Papeša 2007). One archaeobotanical sample was collected from Grave 5 around the left arm of the female skeleton (aged 30-35) in an area where a large chalk bead and a number of small green beads were found. Grave 5 also contained two coins, one of which was of Constantine II (dating to $337-361 \mathrm{AD}$ ) and the second of Constantine the Great (dating to 307-337 AD).

Excavations were also conducted at Lapovačka ulica -Kaufland (VKFL), Vinkovci, where a total of 52 Roman inhumation graves and 2 cremations graves were identified within the western cemetery (Vulić and Rapan Papeša 2009). Almost all of the graves date to the 3-5th century AD and many of the graves had been looted during the Roman period. Samples were collected from five graves with significant finds, but carbonised plant remains were only identified from graves 43,44 and 45 . Grave 43 was a brick built inhumation grave with a rather unusual construction dating to ca. 4 th century AD containing a female aged between 40 to 50 years, based on the density of the trabecular bone and the presence of degenerative changes. Graves 44 and 45 were cremation graves (busta) dating to the first half of the 3 rd century AD. Grave 44 is believed to have been the remains of a female aged 20 to 35 years, while grave 45 was a child aged 6-9 years that was buried with another foetus. Grave goods in the inhumation included finds of unidentified metal, while grave 44 contained evidence of animal bones. Grave 45 is particularly interesting as a large number of grave goods including pottery vessels, remains of animal bones from large and small animals and two glass fragments were recovered (Figure 2). 


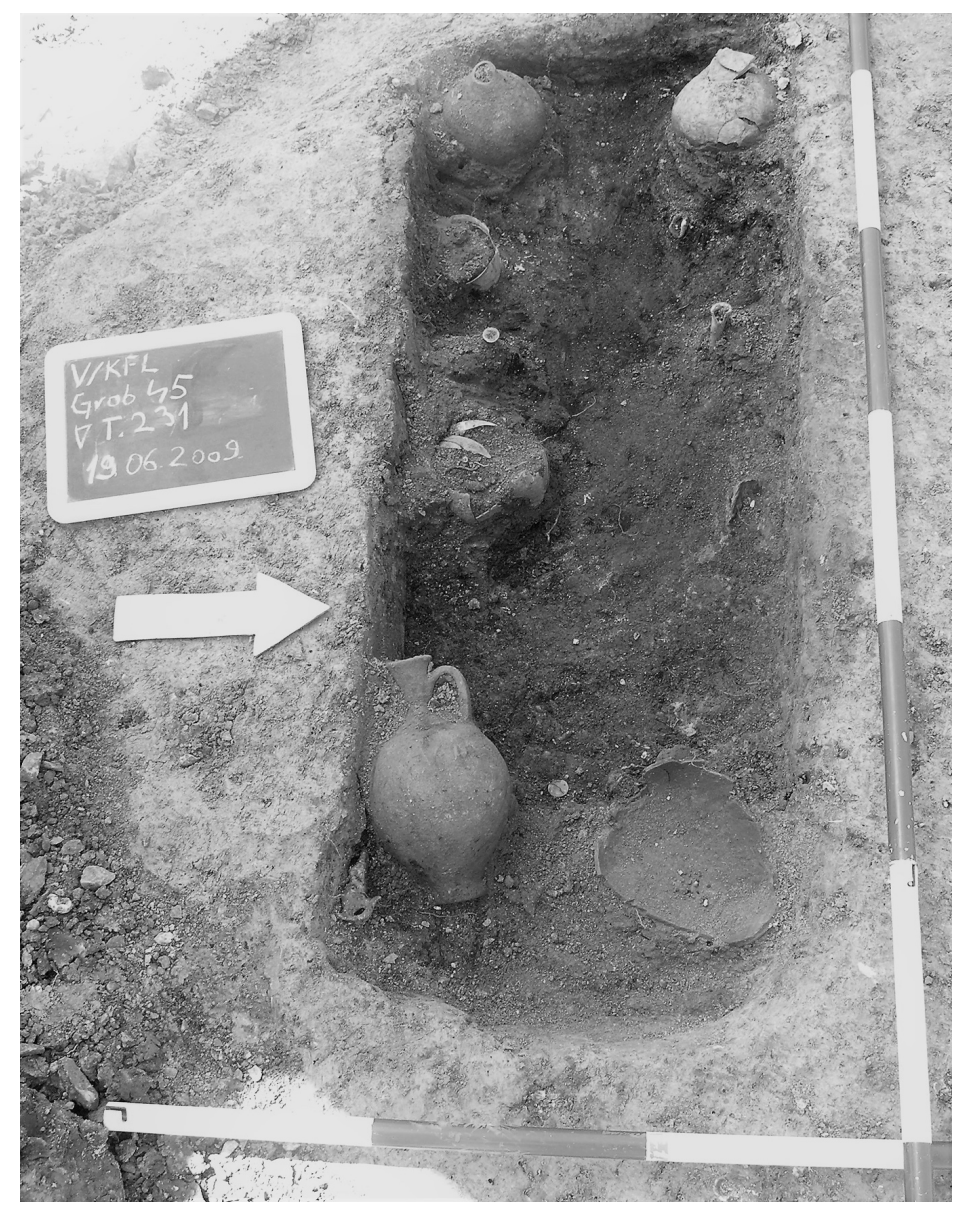

Figure 2. Image of Grave 45, Lapovačka ulica-Kaufland, Vinkovci. Image, Photo Archive of Vinkovci Museum.

Excavations at Ulica I. Gundulića 39 (VIG39), Vinkovci, identified the outside walls of a dwelling located at the very edge of the fortified town of Cibalae, near the western part of the fortification system. Of note was the discovery of an altar dedicated to Silvanus Domesticus and a number of coins of Constantius II dated to 357-358 AD. The altar dedicated to Silvanus Domesticus was situated near the exterior wall of the house, in the courtyard, and was typical of a private household sanctuary (Perinic Muratović and Vulić 2009). The monument was not built into the wall but was found collapsed face down on the wall. It was made of limestone and although the lower part is damaged, the entire front side with the inscription looks as if it has been coated in white with red paint for the letters. The altar reads, Silvano / Domestico / Fl(avius) Ingenu(us) or Ingenu/us (Perinic Muratović and Vulić 2009). The back of the monument does not appear finished and so it is suggested that the monument rested against the wall. During the excavations an area associated with the alter was sampled for archaeobotanical remains.

\section{The archaeobotanical data}

Sample sizes were not recorded, but the excavator estimated that a bucket was collected (approximately 10 litres) from each of the contexts. Systematic sampling was not practiced during excavation but rather judgement samples were collected by the archaeologists in charge. 
Samples were processed using a flotation machine at Vinkovci and bucket flotation at Osijek and collected in a $300 \mu \mathrm{m}$ sieve for the flot and a $1 \mathrm{~mm}$ mesh for the residue. All seeds, fruits and other plant remains were sorted and identified with the aid of a low power (7-40x) binocular microscope. Charred plant macrofossils were identified and recorded using reference literature (Cappers et al. 2006; Jacomet 2006) and a modern reference collection where necessary. A standardised counting method was used involving each grain being counted as one; fragments of grains being combined and estimated as to the number of complete grains they represent; the weed and fruit seeds were all counted as one, with the exception of large seed fragments that clearly represent part of the same seed.

Comparative data were also collected from cremation burials, temples and shrine sites dating to the Roman period across the Roman Empire. Due to different taphonomic processes and sampling methods used only presence/absence data were recorded per site. If more than one grave was sampled then the overall start and end date of the site was recorded.

\section{Results}

At 120 Divaltova Street (OSDIV) Grave 28 contained a fragment of a cereal grain and a pulse, while grave 23 had seven relatively well preserved lentils (Lens culinaris), along with some cereal grain fragments (Table 1).

In Vinkovci the sample taken from Grave 5 at Ulica I. Gundulića 48 (VIG48) contained a total of 42 identifiable plant remains (Table 1). The assemblage was largely dominated by wild/weed species; however, barley (Hordeum vulgare) and spelt (Triticum spelta) were both identified along with one seed of flax (Linum usitatissimum). The wild/weed seeds include a number of grasses (Bromus sp., Poa sp.), sedges (Carex sp.) and rushes (Scirpus sp., Eleocharis palustris).

At Lapovačka ulica -Kaufland (VKFL) only 19 carbonised seeds were identified from graves 44 and 45 and were very similar in composition. Both contained a couple of broomcorn millet grains (Panicum miliaceum), lentil, grass pea (Lathyrus sativus) and other pulse and cereal fragments that were too poorly preserved to identify (Table 1). In addition, grave 44 also contained ca. 30 carbonised fragments of amorphous food remains, which may indicate the remains of a prepared meal or the flesh of fruits (Figure 3a). In grave 43 only four carbonised seeds were recovered, including one barley grain (Figure 3b) and a couple of cereal and pulse fragments.

The one sample collected from a context associated with the alter at Ulica I. Gundulića 39 (VIG39) was largely dominated by cereals remains, barley, naked wheat (Triticum aestivum/durum) and broomcorn millet, with only one indeterminate pulse fragment and four weed seeds identified. 

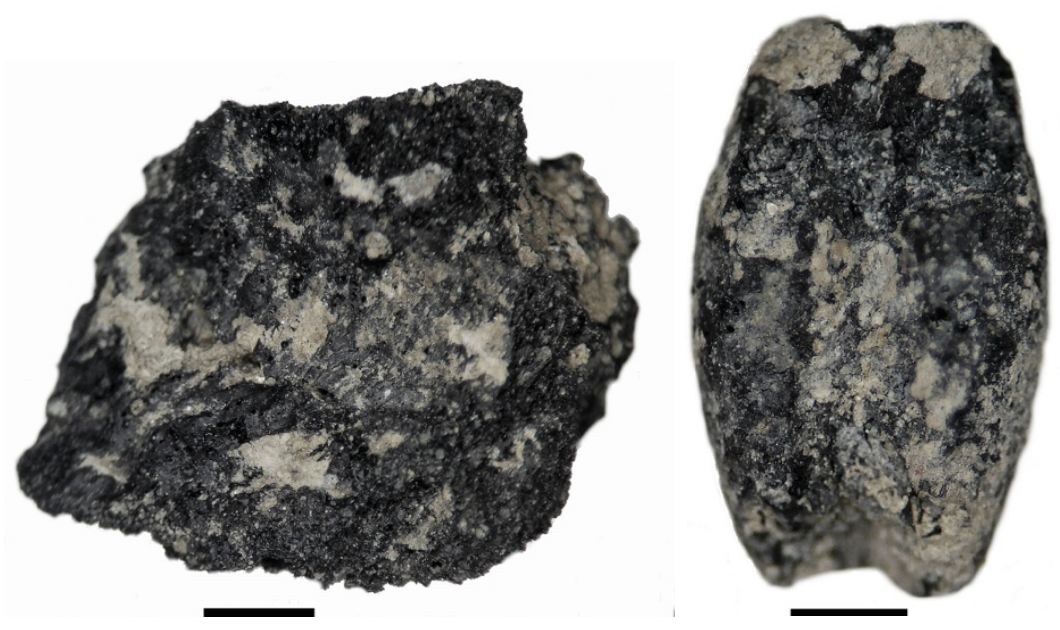

Figure 3. Carbonised macro-remains from Grave 44, Lapovačka ulica-Kaufland, Vinkovci. (a) amorphous material, possibly prepared food and (b) barley (Hordeum vulgare) grain. Scale bar $=1 \mathrm{~mm}$. Images K. Reed.

\section{Discussion}

Over the last 20 years an increasing number of plant remains have been reported on from ritual deposits. These range from domestic offerings (e.g. Robinson 2002), offerings in public temples (Zach 2002), Romano-Celtic temples (e.g. Vandorpe and Jacomet 2011), mithraea (e.g. Martens 2004), and cremation burials (e.g. Kreuz 2000). However, the identification of plant remains deriving from purposeful ritual or religious activities is not simple (Lodwick 2015). Preservation of plant remains in ritual contexts usually depends upon human practices, especially the use of fire in the case of carbonised remains, although preservation through waterlogging and mineralization can also occur. Other taphonomic aspects also need to be considered, especially as carbonised remains can survive for long periods and could be re-deposited in disturbed contexts (e.g. Pelling et al. 2015).

\section{Cremation burials}

Communal feasting was an important part of the funeral process (Williams 2004) and throwing food onto the pyre would have allowed, for instance, the deceased to take part, providing sustenance for their journey to the afterlife (Philpott 1991, 237). Cremation rituals therefore represent a perfect opportunity for the preservation of plant and food remains, but even then not all plant items will preserve through carbonisation. Plant and food remains can derive from several stages in a cremation burial and associated activities. First, in bustum burials, where cremations take place directly over the grave, plants used as fuel, food placed on the pyre, or surrounding vegetation accidentally incorporated in the fire will end up in the grave (Kreuz 2000). Second, are ritual pits, where the cremation has taken place in one area, such as a ustrinum, and the ashes and pyre are re-deposited in a pit or inside an urn. Thus, only an anthropogenic selection of plant and food remains from the pyre will be recovered (Kreuz 2000; Rottoli and Castiglioni 2011). Thirdly, plant remains may derive from funerary meals, although the remains are less likely to be preserved unless there is evidence of hearths 
and cooking/eating vessels found within cemetery sites (e.g. Toynbee 1996, 50-1, 63-4; Biddulph and Booth 2006; Jensen 2008,120).

The plant remains recovered from the two undisturbed bustum graves at VKFL could be interpreted as pyre offerings. The graves also included possible remains of some form of bread/cakes/pastry; similar finds in northern Italy were identified as burial offerings (Rottoli and Castiglioni 2011). Although the densities are relatively low, similar densities of plant remains have been recovered from other cremation burials throughout the provinces (e.g. Gray 2008).

The two undisturbed cremation burials at OSDIV could also represent pyre offerings. In particular, the well preserved lentil remains could possibly indicate the throwing of dried, raw lentils onto the pyre. If they had been cooked the lentils would have been soft, making it more unlikely to survive in a recognisable state (Barber and Bowsher 2000). Furthermore, literary evidence records that at early Roman funerary feasts the food given to the dead was raw (Scheid 1984). Pulses are particularly interesting as some suggest that they hold possible religious or mystical attributes (Barber and Bowsher 2000, 70, 308). According to ancient texts pulses were eaten during the Parentalia festival that honoured the family, at the silicernium, on the day of burial as a grave-side meal of purification, and then again nine days later at the cena novendialis, which represented the end of the official mourning period (Lindsay 1998, 72; 75; Jensen 2008, 117).

The tradition of incorporating plants within cremation burials is unlikely to have been new for Pannonia. Although systematic archaeobotanical sampling at Iron Age and Roman sites is not common in Croatia, the early Iron Age Hallstatt necropolis of Kaptol-Gradci, approximately $100 \mathrm{~km}$ west of the study sites, has produced evidence of archaeobotanical remains within cremation burials. Here the tumuli were reported to contain predominantly cereal grains as well as small quantity of weeds representing accidental inclusions and wild fruits, primarily wild apples (Malus sylvestris) (Šoštarić et al. 2017). The incorporation of plants within cremations is also widespread in pre-Roman Italy, especially cultivated and uncultivated fruits and nuts such as grapes, acorns (Quercus sp.) and dogwood (Cornus sanguinea) (Rottoli and Castiglioni 2011; Caracuta and Fiorentino 2018). This therefore suggests that plant remains continued to be used in cremations, although the rituals behind their incorporation may have changed or been adapted through time. For example, at Ilok, 45-70 km east of the study sites, a number of Roman graves dating to the $1^{\text {st }}$ century AD contained late La Tène pottery suggesting that rural communities held onto the features of their own material culture, incorporating only some of the newly founded Roman provincial culture (Dizdar et al. 2003).

What we do see in Croatia from the Iron Age to the Roman period is the introduction of exotics and a wider range of Mediterranean goods imported into the region. At Ilok, the $1^{\text {st }}$ century AD graves contained calcified remains of melon/cucumber (Cucumis melo/C. sativus), fig (Ficus carica) and olive (Olea europaea), indicating imported goods from the Mediterranean (Šoštarić et al. 2006). In 
Osijek, new excavations from an early 2nd century AD septic pit have revealed the presence of rice (Oryza sativa) and black pepper (Piper nigrum), showing the first evidence of exotics arriving to Pannonia from Asia (Reed and Leleković 2017). Furthermore, to the north in Slovenia remains of dates (Phoenix dactylifera) are seen for the first time in Roman graves at Poetovia and Emona (Kujundžić 1982; Petru 1972). Thus, in the newly assimilated region of Pannonia, the expansion of trade networks and road systems, the establishment of military installations and the founding of Roman Colonia, such Aelia Mursa in Osijek, would have meant a greater access to new food items which could then be incorporated within burial rituals, although none of these were present at the study sites.

\section{Inhumations}

Whether carbonised plant remains can be interpreted as offerings within an inhumation is more difficult, due to the lack of direct burning associated with the burial. Usually a burial is considered the result of a single event and the grave content described as a discrete unit. However, archaeobotanical remains are plagued with problems of intrusion and residuality (e.g. Pelling et al. 2015). This is particularly acute in areas with a long history of human occupation, cultivation, grazing, and bioturbation (Borojevic 2011).

The plant remains from VIG48 are particularly interesting as they contained a relatively large number of wild plants and weed seeds compared to the other sites. These likely represent plants from the local environment that were accidentally burnt and later deposited within the graves. Similarly, the cereals, pulse fragments and flax seed may arguable indicate accidental burning of local crops during ceremonial activities, as these plants have been found within ritual contexts in other provinces (e.g. Zach 2002; Vandrope and Jacomet 2011). However, no areas of burning were identified at the cemetery to indicate other ceremonial activities involving plant remains occurred. Thus, it is possible that the infill of the graves from VIG48 and VKFL43 consisted of a mixture of archaeobotanical remains from different periods, attesting to previous and/or later occupation or use on this site.

\section{Shrines}

Direct association of carbonised plant remains with shrines is also problematic, especially when the shrine is in a settlement where a large range of activities are taking place. The location of the altar at VIG39 was likely located within the courtyard of the house, however, it is difficult to determine conclusively that the burnt remains represent offerings and could instead represent secondary or tertiary deposits buried within the associated context. In particular, the identified remains of cereals, a pulse and a handful of weed seeds could point to kitchen waste. Nevertheless, ancient texts describe the burning of food offerings as part of household rituals. For example, private domestic worship revolved around the household spirits (Vesta, Lares Familiares, Penates, Genius), where offerings of 
plants and animals commonly occurred to honour the deities, especially around meal times (Lyttelton and Foreman 1984, 85; Robinson 2002). Ovid describes how food would be thrown into the fire to be consumed by the household gods (Fasti, VI, 307), while other offerings were burnt on altars (Fasti, I, 343-5) and special pyres (Fasti, II, 533-4). Thus, similarities will exist between the range of plants from a shrine and a settlement (i.e. cereals and pulses), making it unclear whether the plant remains recovered from VIG39 indicate plants used as offerings to the gods.

\section{Plants as offerings in the Roman World}

Recently Elsner (2012) suggested a move from animal sacrifices towards more vegetable offerings (e.g. incense and libations) by the 3rd century AD across much of the Roman Empire, based on a reduction in animal sacrificial imagery (mainly sculptures). For example, animal sacrifice appears in pagan festival scenes from the 2 nd to 3 rd centuries, but by the 4 th these scenes are replaced by images of incense burning or libation (Elsner 2012, 133). But this pattern is not widespread and in North Africa animal sacrifice remains popular in the visual material culture (Elsner 2012, 155). In southern Britain too evidence of animals as offerings (seen from zooarchaeological remains) seems to remain relatively constant until the transition to Christianity in the $5^{\text {th }}$ Century AD (e.g. King 2005). In terms of plant offerings, both written and iconographic evidence is seen from the 1st century AD. For example, pine cones, figs and dates are found on sculptures, wall paintings and mosaics at Pompeii and Herculaneum (Robinson 2002). In the Eastern Mediterranean sarcophagi, statues and grave stele depict evidence of dates, vines, pine cones, wheat, walnuts and many other fruits, with most dating to around the 2nd century AD (Yilmaz et al. 2013). As symbols of fertility and growth, plants were particularly central to cults of Demeter (Roman Ceres) and Dionysus (Roman Bacchus). Pliny (H.N.15.77), Verrius Flaccus (Fest 172.25-174.20) and Tacitus (Ann. 13.58) also note sacred fig trees planted in Rome and offerings of bread or other cereal products are also described, such as a salted cake, mola salsa (Pliny, N.H 18.2; 31.41). But how much can these images and written accounts reflect upon actual ritual offerings across time and space?

The recovery of archaeobotanical remains from cremation burials and shrine sites dating to the $1 \mathrm{st}$ century $\mathrm{BC}$ to the 4 th century $\mathrm{AD}$ are still relatively rare in many regions. Little evidence exists for the Iberian Peninsula, North Africa or much of Southeast Europe. In an attempt to determine whether any spatial and/or chronological patterns in the main species offered in Roman Europe exist and how this fits with prevailing theories and the evidence from Croatia, we present evidence of archaeobotanical data from shrines (Table 2) and cremation burials (Table 3) from across Europe. Only 21 shrines (Romano/Celtic temples, household shrines and public temples) have evidence of archaeobotanical remains (Table 2). In contrast, 135 sites have evidence of plant remains from cremation burials. Although other archaeobotanical data exist from other regions these finds were selected in order to provide enough data to allow regional comparisons within the context of this 
paper. The regions to be examined here include; Region 1 (47 sites from France and 7 sites from Switzerland), Region 2 (18 from Germany, 2 from Belgium, 1 from Luxembourg and 2 from the Netherlands), Region 3 (10 from Hungary, 2 sites from Austria, 1 from Slovenia and the 2 study sites from Croatia), Region 4 (26 sites from Italy), and Region 5 (17 sites from Bulgaria) (Table 3; Figure 4).

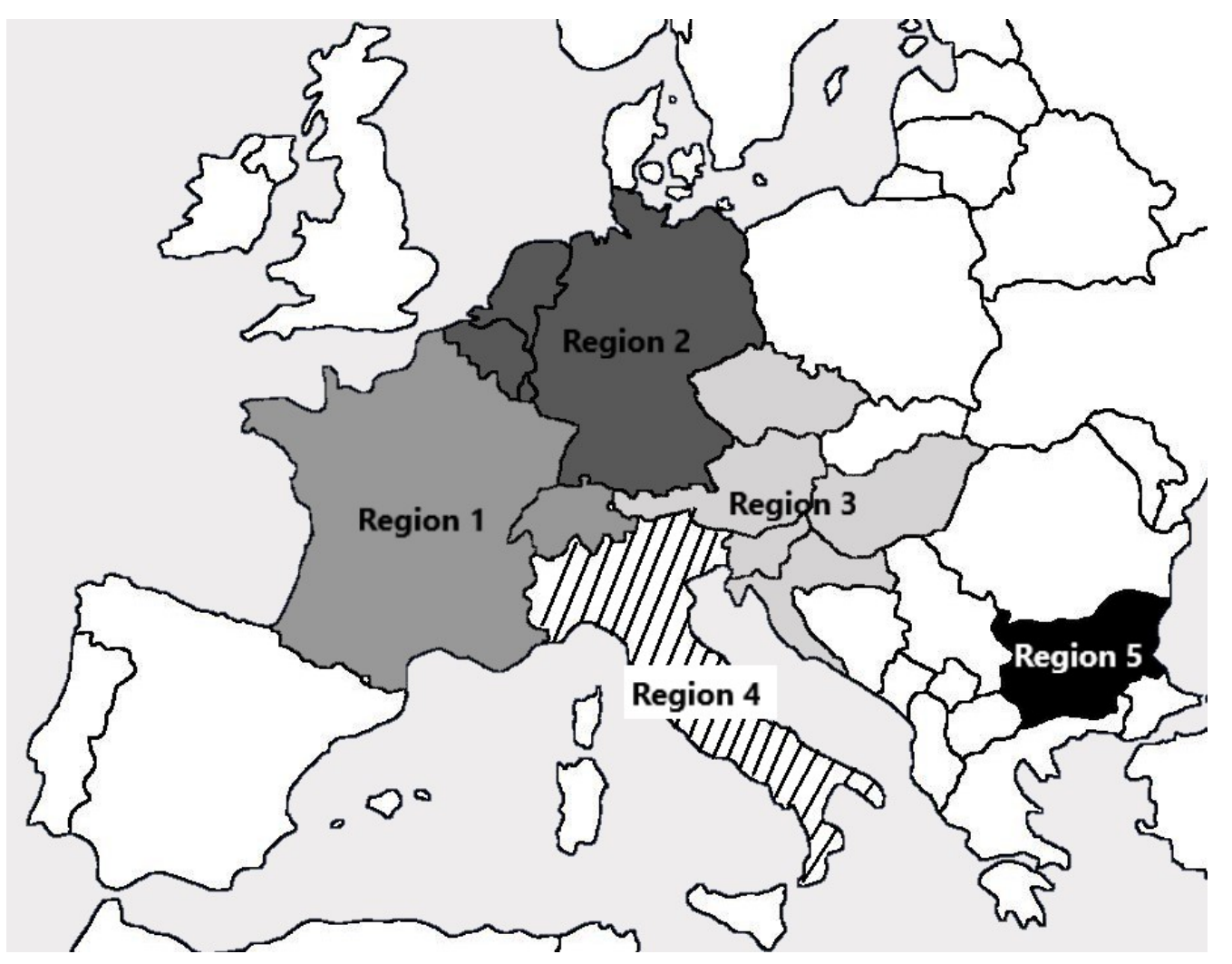

Figure 4. Regions under study that contain sites with archaeobotanical remains from cremation burials.

Overall, the composition of the archaeobotanical remains from shrine sites shows a dominance of fruits and nuts with $85 \%$ of the sites containing these remains, followed by $50 \%$ containing cereals (Figure 5). Similarly, the plant remains recovered from cremations burials also show a high presence of fruit and nut remains being present at $75 \%$ of the sites, followed by $50 \%$ containing cereals. Looking at the ubiquity of each species, pine nuts (Pinus pinea), date (Phoenix dactylifera) and fig (Ficus carica) dominate the shrine sites, while hazelnut (Corylus avellana), barley (Hordeum vulgare) and walnut (Juglans regia) dominate the cremations. Regional comparison of the cremation sites also show a high percentage of fruit and nut remains compared to other remains, although regions 1 and 2 also have a high presence of cereals and pulses (Figure 6). In particular, the cremations from Bulgaria all contained fruits and nuts and little else, with $88 \%$ of the sites containing remains of walnuts (Hristova 2015). While taphonomic bias is likely and regional variations per site should be considered, the results here show a clear overall prevalence of fruit and nut offerings compared to the other plant categories at both shrine and cremation sites. The relatively high presence of date in both 
cremations and shrines may be linked to suggestions that date had strong ceremonial connotations (Livarda 2013).

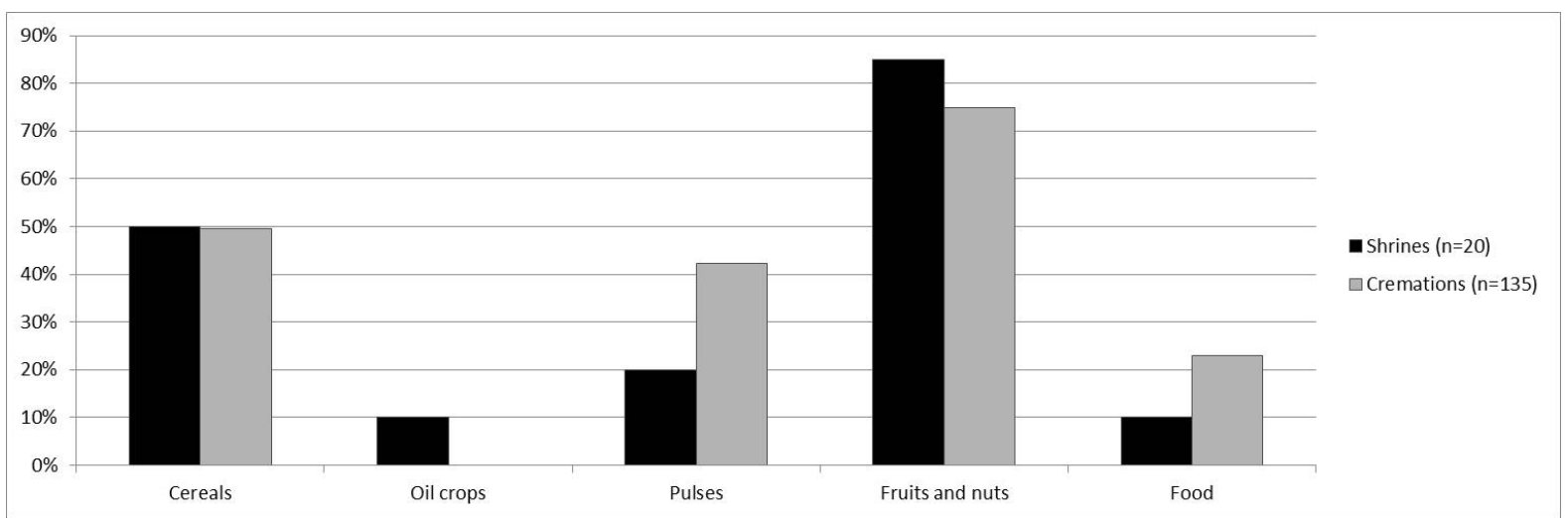

Figure 5. Number of sites within which the main plant categories are present.

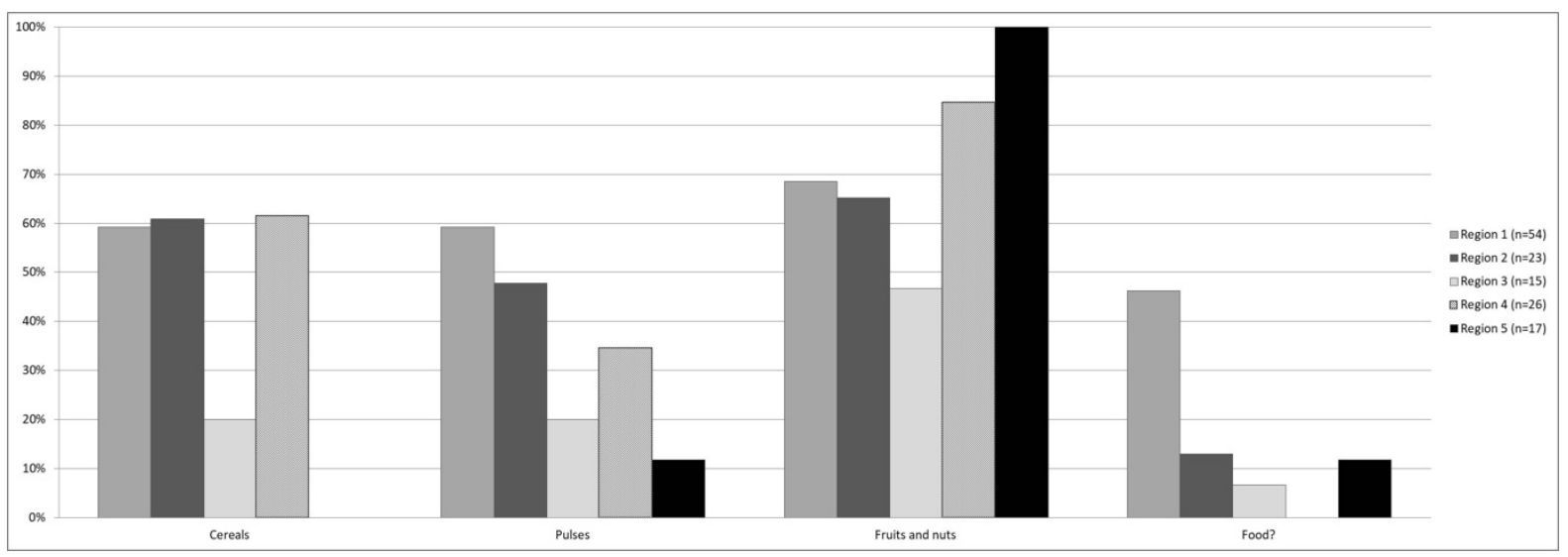

Figure 6. Number of sites in which the main plant categories are present per region.

Looking at the ubiquity of the plant remains per region, both Regions 1 and 2 (north-west) have a high presence of barley (ca. 50\%), followed by hazelnut (44\%, 52\%), lentil (ca. 40\%), pea (33\%, 39\%) and bean (ca. 39\%). Region 1 also has a relatively high presence of possible food remains (46\%). In contrast, Region 4 is dominated by date (53\%), figs (50\%) and walnuts (50\%) and Region 5, walnuts $(100 \%)$. Region 3 only has one or two seeds of any one species and so no pattern can be discerned here. The remains from Regions 1 and 2 (north-west) therefore show a higher preference for cereals and pulses compared to Regions 4 and 5 (south-east), which showed a higher presence of fruit and nut remains. Could this indicate differences in regional traditions, where the plant offerings represent new forms of religious communication created out of cultural and economic interactions at the local and regional scale? Is this simply the result of what was most commonly available and accessible to the local inhabitants, particularly as figs, walnuts and dates would have had to have been imported into the regions of France and Germany? Or is this simply bias in the datasets? 
Examining the data through time, there is no clear pattern between the regions or from the dataset as a whole. The problem of dating the ritual sites limits any conclusions about possible chronological changes in the use of plant offerings. In addition, the increase of inhumation burials from the $2 \mathrm{nd} / 3 \mathrm{rd}$ century (e.g. Morris 1992; Leleković 2012; Graham and Hope 2016) also reduces the chances of plant remains becoming preserved by charring. This means that the archaeobotanical dataset presented here is biased towards the earlier periods where cremation burials were more common (only 10 sites have deposits later than the $3^{\text {rd }}$ century A.D.). What is clear is that plant remains were commonly found within ritual contexts from the 1st century AD, which may support Elsner's (2012) conclusion that the significance of animal sacrifice may be exaggerated within the general ritual complex of Roman religion.

Looking at the shrine sites, the types of plants offered does not seem to change, with no clear patterning between the types of plants offered to different deities. For example, pine cones are found at 1 st century $\mathrm{AD}$ shrines dedicated to Isis and Lares at Pompeii and at $3^{\text {rd }}-4^{\text {th }}$ century shrines dedicated to Mithras and Anna Perenna and fig at the 2nd to 3rd century AD shrines dedicated to Isis (Spain), Melikertes-Palaimon (Greece), Fortuna (Netherlands) and Hercules (Netherlands) (Table 2). Regionally, the four UK sites only have the presence of hazelnut, pine cones and one record of date at Rochester. Similarly, the Netherlands and Belgium sites have limited remains. In contrast, the three French sites and the four Italian sites have a greater range of plant remains including the presence of fig, walnut, olive and grape. Again, could the offerings present in particular regions be a result of what was most commonly available and accessible to the local inhabitants? Or is this simply bias in the datasets? For example, good preservation of carbonised plant remains were recorded from a hearth and offering pit at Oedenburg, where one pit sample had 50.3 items per litre (Vandorpe and Jacomet 2011). As a result, the site yielded a wide range of cereals, legumes, fruits and nuts, including 596 pine nuts in offering pit 160/219 and the only find of garlic in this dataset. In contrast, the density of plant remains at Ulica I. Gundulića 39 was only 2.3 identified items per litre.

\section{Conclusions}

New plant remains were collected from inhumations, cremations and an altar dedicated to Silvanus Domesticus, from the Province of Pannonia Inferior (present-day eastern Croatia). The archaeobotanical remains from the cremation burials likely represent pyre offerings, such as possible raw lentils and some form of bread/cakes/pastry. The plant remains found in association with the altar dedicated to Silvanus Domesticus at Ulica I. Gundulića 39 may also indicate offerings of cereals to the deity, although direct association with the altar is difficult to determine conclusively. In contrast, the plant remains from the inhumations probably represent occupation waste rather than offerings to the dead. 
Comparison of the Croatian data with plant remains from shrines and cremations located in Europe show that what might be termed more 'local' or 'common' food plants (e.g. wheat, pulses, local fruits and nuts), were being incorporated within religious activities. This also supports the assumption that the more common crop remains recovered from the Croatian cremation burials represent plant offerings. The evidence from the shrine data, although limited in comparison to the cremations, shows no pattern in specific offerings being associated with specific deities. Regionally, the differences seen in the cremation burials, where those in north-western Europe were more likely to contain cereals and pulses and those in south-eastern Europe showed a higher presence of fruit and nut remains, are likely due to the influence of imported religious customs and local religious choice. In addition, the access and availability of certain plant remains would have been a major factor in how groups or individuals conducted religious practices, adapting certain forms of material culture and associated meanings to what was available (e.g. fewer exotic imports seen in cremations in the provinces of France and Germany). Unfortunately exploring the adaptation and expression of groups or individual religious practices in relation to plant offerings is limited at present, due in part to small datasets and the problem of dating burials, restricting detailed analyses of chronological changes. It is therefore important that environmental samples are collected from Roman ritual contexts in order to understand the relationship between plants and religion, especially in understudied parts of the empire.

\section{Acknowledgements}

Many thanks to colleagues, especially Angela Kreuz, Helmut Kroll, Patricia Vandorpe, Nadja Hasslinger, Margarethe König and Julian Wiethold, for suggesting sites to examine and articles to read. Thanks also to the two anonymous referees and Alexadra Livarda for their helpful and constructive comments on previous drafts of this paper.

\section{References}

Aldrete, Gregory S. 2014. "Hammers, axes, bulls, and blood: some practical aspects of Roman animal sacrifice." Journal of Roman Studies 104: 28-50.

Audollent, Auguste. 1922. "Les tombes gallo-romaines à inhumation des Martres-de-Veyre." Mémoires présentés par divers savants à l'Académie des Inscriptions et Belles Lettres 13: 275-328.

Barber, Bruno, and David Bowsher. 2000. The eastern cemetery of Roman London: Excavations 1983-1990. London: MoLAS Monograph 4.

Barnes, Timothy D. 1987. "Himerius and the fourth century." Classical Philology 82(3): 206-225

Béal, Jean-Claude. 1994. "Le sanctuaire des Basaltes à Alba-La-Romaine (Ardèche) et ses offrandes." In Les Sanctuaires de Tradition Indigène en Gaule Romaine (Paris), edited by Christian Goudineau, Isabelle Fauduet, and Gérard Coulon, 161-168. Paris: Musée d'Argentomagus. 
Bianchetti Enrico. 1895. I sepolcreti di Ornavasso: cento anni di studi. Atti della Società di archeologia e belle arti per la provincia di Torino VI. Rome: L. Nardini.

Biddulph, Edward, and Paul Booth. 2006. The Roman Cemetery at Pepper Hill, Southfleet, Kent. Oxford: Oxford Wessex Archaeology Joint Venture (London and Continental Railways).

Blänkle, Peter H, Angela Kreuz, and Vera Rupp. 1995. "Archäologische und naturwissenschaftliche Untersuchungen an zwei römischen Brandgräbern in der Wetterau.” Germania 73 (1): 103-130.

Borojevic, Ksenija. 2011. "Interpreting, dating, and reevaluating the botanical assemblage from tell Kedesh: a case study of historical contamination." Journal of Archaeological Science 38: 829-842.

Bouby, Laurent, and Philippe Marinval. 2004. "Fruits and seeds from Roman cremations in Limagne (Massif Central) and spatial variability of plant offerings in France." Journal of Archaeological Science 31: 77-86.

Brusin, Giovanni. 1934. Gli scavi di Aquileia. Udine: Editoriale Libraria S.A.

Bult, Epko J., P. van der Hout, and T. Immerzeel. 1988. "Een Romeins grafveldje aan de Tiendweg bij Naaldwijk." Westerheem 37: 118-125.

Campbell, Duncan B. 2013. The Rise of Imperial Rome AD 14-193. Oxford: Osprey Publishing.

Camps, J., and D. Barraud. 1981. "La nécropole à incinération de la villa de Monségur (Gironde)." Revue archéologique Sites 11: 15-16.

Cappers, René T.J., R.M. Bekker, and J.E.A. Jans. 2006. Digital Seed Atlas of the Netherlands. Groningen Archaeological Studies. 4. Eelde: Barkhuis

Caracuta, Valentina, and Girolamo Fiorentino. 2018. "Plant Rituals and Fuel in Roman Cemeteries of Apulia (SE Italy)." In The Bioarchaeology of Ritual and Religion edited by Alexandra Livarda, Richard Madgwick, and Santiago Riera Mora, 58-68. Oxford: Oxbow books.Christie, Neil. 1992. "The survival of Roman settlement along the Middle Danube: Pannonia from the fourth to the tenth century AD." Oxford Journal of Archaeology 11(3): 317-339.

Collis, John, Brian Hartley, Brenda Dickinson, Mark Maltby, Coralie Mills, Calvin Wells, and Derrick Webley. 1990. "Incinération gallo-romaine á Lussat et fouilles de sauvetage en Grande-Limagne (Puy-de-Dôme) en 1976." Revue Archéologique du Centre 29 (1): 5-17.

Cooremans, Brigitte. 2004. "Palaeobotanical research." In Roman Mithraism: the evidence of the small finds edited by Marleen Martens, and Guy De Boe, 49-51. Brussels: Institute for the Archaeological Heritage.

Cooremans, Brigitte. 2008. "The Roman cemeteries of Tienen and Tongeren: results from archaeobotanical analysis of the cremation graves." Vegetation History and Archaeobotany 17: 3-1.

Cordie-Hackenberg, Rosemarie, C. Gerdes, and A.Wigg. 1992. "Nahrungsreste aus Römischen Gräbern undAschen- gruben desTrierer Landes.” Archäologisches Korrespondenzblatt 22: 109-117.

Dizdar, Marko, Renata Šoštarić, and Kristina Jelinčić. 2003. “An early Roman grave from Ilok as a contribution to understanding a process of the romanization of western Syrmia.” Prilozi 20: 57-77.

Dussot, Dominique. 1987. "Les nécropoles de la Creuse." In Nécropoles à incinération du Haut-Empire: Table Ronde Lyon, 30 et 31 mai 1986 edited by France, Ministère de la culture et de la communication, 123-127. Lyon: Région Rhône-Alpes, Direction des antiquités historiques.

Džino, Danijel. 2010. "Aspects of identity-construction and cultural mimicry among the Dalmatian sailors in the Roman navy.” Antichthon: Journal of Australasian Society for Classical Studies 44: 96-110.

Džino, Danijel. 2012. "The cult of Silvanus: rethinking provincial identities in Roman Dalmatia." Vjesnik Arheoloskog muzeja u Zagrebu 45: 261-279.

Džino, Danijel, and Alka Domić-Kunić. 2012. "Pannonians: identity-perceptions from the Late Iron Age to later antiquity." In The Archaeology of Roman Southern Pannonia. The State of Research and Selected Problems in 
the Croatian Part of the Roman Province of Pannonia, British Archaeological Reports 2393, edited by Branka Migotti, 93-115. Oxford: Archaeopress.

Elsner, Jaś. 2012. "Sacrifice in late Roman art." In Greek and Roman Animal Sacrifice: Ancient Victims, Modern Observers edited by Christopher A. Faraone and F.S. Naiden. Cambridge: Cambridge University Press.

Ferdiére, Alain. 1988. Les Campagnes en Gaule romaine, vol. 2, Les techniques et les productions rurales en Gaule. Paris: Errance.

Fitz, Jenő, ed. 1998. Religions and Cults in Pannonia. Hungary: Fejér Megyei Múzeumok Igazgatósága.

Gebhard, Elizabeth R., Frederick P. Hemans, and John W. Hayes. 1998. "University of Chicago Excavations at Isthmia, 1989: III.” Hesperia 67: 405-456.

Gose, Erich. 1972. Der gallo-römische Tempelbezirk im Altbachtal zu Trier. Mainz: Zabern.

Graham, Emma-Jane. and Valerie M. Hope. 2016. "Funerary Practices." In A Companion to Roman Italy, edited by Alison E. Cooley, 159-180. London: Wiley-Blackwell.

Gray, Lisa. 2008. "Charred plant remains." In The Archaeology of the M6 Toll, 2000-2003. Salisbury, edited by Andrew B. Powell, Paul Booth, A. P. Fitzpatrick, and A. D. Crockett, 173-176. Oxford: Wessex Archaeology.

Grimes, William F. 1968. The Excavation of Roman and Mediaeval London. London: Routledge.

Groenman-van Waateringe, Willy, and Jan-Peter Pals. 1994. "De vegetatie op en rondom het heiligdom." In De tempel van Empel: een Herculesheiligdom in het woongebied van de Bataven, Graven naar het Brabantse Verleden 2, edited by Ton Derks, and Nico Roymans, 72-81. s'Hertogenbosch: Stichting Brabantse Regionale Geschiedbeoefening.

Gyulai, Ferenc. 2002. "Die pflanzenreste des in Dunakeszi-Székesdűlő freigelegten spätbronzezeitlichen Röhrenbrunnens." Budapest Régiségei 36: 301-307

Gyulai, Ferenc. 2010. Archaeobotany in Hungary. Seed, Fruit, Food and Beverage Remains in the Carpathian Basin from the Neolithic to the Late Middle Ages. Budapest: Archaeolingua.

Haberey, W. 1948. "Römische Grabhügel in Monreal (Kreis Mayen).” Bonner Jahrbuch 148: 426.

Hänninen Kristi, and Caroline Vermeeren. 1997. "Exotische offers. Exotische offers. Botanisch onderzoek aan kuilt uit de Romeinse Fortuna-tempel op het Maasplein in Nijmegen.” BIAXiaal 51: 1-11.

Hartyányi Borbála P., G Nováki, and A Patay. 1967/68. "Növényi Mag-és Termésletek Magyarországon az Újkıkortól a XVIII.” Magyar Mezögazdasági Múzeum Közleményei 1967-1968: 5-85.

Hartyányi Borbála P., and G. Nováki. 1975. "Samen- und Fruchtfunde in Ungarn von der. Neusteineinzeit bis zum 18. Jahrhunderten.” Agrártörténeti Szemle XVII: 1-65.

Heiss, Andreas G., Nathalie Pouget, Julian Wiethold, Anne Delor-Ahü, and Isabelle Le Goff. 2015. "Tissue Based Analysis of a Charred Flat Bread (galette) from a Roman Cemetery at Saint-Memmie (Dép. Marne, Champagne-Ardenne, north-eastern France).” Journal of Archaeological Science 55: 71-82.

Helbaek, Hans. 1956. "Vegetables in the funeral meals of pre-urban Rome (Appendix 1)." In Early Rome, vol. 2, edited by Einar Gjerstad, 287-294, Lund: Gleerup.

Hintermann, Dorothea. 1995. Windisch-Dägerli: ein römerzeitliches Gräberfeld vom Ende des 1. Jh. nach Christus. Lizentiatsarbeit: University of Zurich.

Hristova, Ivanka. 2015. "The use of plants in ritual context during Antiquity in Bulgaria: overview of the archaeobotanical evidence.” Bulgarian E-Journal of Archaeology 5: 117-135.

Jacomet, Stefanie. 1986. "Verkohlte Pflanzenreste aus einem römischen Grabmonument beim Augster Osttor (1966)." Jahresberichte aus Augst und Kaiseraugst 6: 7-53.

Jacomet, Stefanie. 2006. Identification of Cereal Remains from Archaeological Sites (2nd Ed.). Basel: Institute for Prehistory and Archaeological Science. 
Jacomet, Stefanie, and Marianne Bavaud. 1992. "Verkohlte Pflanzenreste aus dem Bereich des Grabmonumentes ("Rundbau") beim Osttor von Augusta Raurica: Ergebnisse der Nachgrabungen von 1991." Jahresberichte aus Augst und Kaiseraugst 13: 103-111.

Jensen, Robin. 2008. "Dining with the Dead: From the Mensa to the Altar in Christian Late Antiquity." In Commemorating the Dead Texts and Artifacts in Context: Studies of Roman, Jewish, and Christian Burials, edited by Laurie Brink, and Deborah A. Green, 107-144. New York: Walter de Gruyter.

Karnitsch, Paul. 1956. "Der Heilige Bezirk von Lentia.” Historisches Jahrbuch der Stadt Linz 5: 189-287.

King, Anthony. 2005. “Animal remains from temples in Roman Britain.” Britannia 36: 329-70.

Knörzer, Karl-Heinz. 1980. "Römische und mittelalterliche Pflanzenfunde vom Münsterplatz in Neuss." Bonner Jahrbücher 180: 581-584.

König, Margarethe. 1989. “Über die Haselnuß (Corylus avellana L.) als prähistorische Nahrungspflanze.” Funde und Ausgrabungen im Bezirk Trier 21:3-6.

König, Margarethe. 1991. "Die vegetabilischen Beigaben aus dem gallo-römischen Gräberfeld WederathBelginum im Hunsrück.” Funde und Ausgrabungen im Bezirk Trier 23: 11 - 19.

König, Margarethe. 1995. "Botanische Grabinhalte und ihre Aussagemöglichkeiten.” In Des Lichtes beraubt, Totenehrung in der romischen Gr berstrasse von Mainz-Weisenau, edited by Marion Witteyer, and Peter Fasold, 139-143. Wiesbaden: Katalog zur Ausstellung.

Kreuz, Angela. 1995. "Pflanzenreste aus römischen Brandgräbern und ihre kulturhistorische, agrar- und vegetationsgeschichtliche Bedeutung." Germania 73 (1): 110-123.

Kreuz, Angela. 2000. "Functional and conceptual archaeobotanical data from Roman cremations." In Burial, Society and Context in the Roman World, edited by John Pearce, Martin Millett, and Manuela Struck, 45-51. Oxford: Oxbow Books.

Kroll, Helmut. 1999. “Zu den Pflanzenfunden aus den Grabgefässen von Lamadelaine.” In Lamadelaine, une nécropole de l'oppidum du Titelberg, edited by Patrice Méniel, Nicole Metzler-Zens, and Jeannot Metzler, 282284. Luxembourg: Dossiers d'archéologie du musée national d'histoire et d'art, 6.

Kroll, Helmut. 2005. "Eine Handvoll Linsen - Zu den Pflanzenfunden aus den Gräbern von Hoppstädten.” In Studien zu den sozialen Strukturen der historischen Kelten in Mitteleuropa aufgrund der Gräberanalyse. Die keltisch-römische Nekropole von Hoppstädten-Weiersbach im Kontext latènezeitlicher Fundgruppen und römischer Okkupation edited by Ralf Gleser, 533-564. Bonn: Rudolf Habelt Gmbh.

Kujundžić, Zilka.1982. Poetovijske nekropole. Katalogi in Monografije 20. Ljubljana: Narodni muzej u Ljubljani.

Leleković, Tino. 2012. “Cemeteries.” In The Archaeology of Roman Southern Pannonia. The State of Research and Selected Problems in the Croatian Part of the Roman Province of Pannonia, British Archaeological Reports 2393, edited by Branka Migotti, 313-357. Oxford: Archaeopress.

Lequoy, M-Cl. 1987. "La nécropole gallo-romaine de Vatteville-LaRue (forêt de Brotonne-Les-Landes, SeineMaritime)." Nécropoles à incinération du Haut-Empire, Actes Table Ronde (Lyon, 30-31 mai 1986), RAPRRA, 4: $55-68$.

Lignereux, Yves, et al. 1997., after Mégaloudi, Fragkiska. 2005. "Burnt sacrificial plant offerings in Hellenistic times: an archaeobotanical case study from Messene, Peloponnese, Greece." Vegetation History and Archaeobotany 14: 329-340.

Lindsay, Hugh. 1998. "Eating with the dead." In Meals in a social context-aspects of the communal meal in the Hellenistic and Roman World, edited by Inge Nielsen and Hanne S. Nielsen, 67-80. Aarhus: Aarhus University Press.

Lintz, Guy. 1991. "Sépultures gallo-romaines des Ribières (commune de Bessines, Haute- Vienne)." Trav. d' Archéol. Limousine 11: 65-89. 
Livarda, Alexandra. 2013. "Date, rituals and socio-cultural identity in the North-western roman provinces." Oxford Journal of Archaeology 32 (1): 101-117.

Lodwick, Lisa. 2015. "Identifying ritual deposition of plant remains: a case study of stone pine cones in Roman Britain." In TRAC 2014: Proceedings of the Twenty-Fourth Annual Theoretical Roman Archaeology Conference, edited by Tom Brindle, Martyn Allen, Emma Durham, and Alex Smith, 54-69. Oxford: Oxbow.

Lyttelton, Margaret, and Werner Forman. 1984. The Romans: Their Gods and their Beliefs. London: Orbis.

Macher Mathias. 1851. "Die Römer-Gräber in der Gegend von Hartberg." Mitteil, des historischen Vereines für Steiermark 2: 107-126.

Marinval Philippe. 1990. "Analyse carpologique de deux incinérations aux Ribiéres, Bessines-sur-Gartempe (Haute-Vienne).” Travaux d'archéologie Limousine 11: 90-99.

Marinval, Philippe. 1993. "Etude carpologique d'offrandes alimentaires végétales dans les sépultures galloromaines: reflexions preliminaries." Supplément à la Revue archéologique du centre de la France 6 (1):45-65

Marinval, Philippe. 2001. "Offrandes végétales de la nécropole gallo-romaine des Sagnes à Pontarion (Creuse)." In La nécropole gallo-romaine des Sagnes à Pontarion (Creuse), edited by Guy Lintz, 191-196. Pontarion: Association des publications chauvinoises.

Martens, Marleen. 2004. "Re-thinking sacred "rubbish": the ritual deposits of the temple of Mithras at Tienen (Belgium)." Journal of Roman Archaeology 17: 333-353.

Monckton, Angela. 2000. "Charred plant remains." In The Excavation of a Romano-British Shrine at Orton's Pasture, Rocester, Staffordshire, British Archaeological Report 314, edited by Iain Ferris, Lynne Bevan, and Richard Cutler, 67-71, 91. Oxford: Archaeopress.

Morris, Ian. 1992. Death Ritual and Social Structure in Classical Antiquity. Cambridge: Cambridge University Press.

Morris, James. 2011. “Animal 'Ritual' Killing: from Remains to Meanings.” In The Ritual Killing and Burial of Animals: European Perspectives, edited by Aleksander Pluskowski, 8-21. Oxford: Oxbow.

Murphy, Charlene, Gill Thompson, and Dorian Fuller. 2013. "Roman food refuse: urban archaeobotany in Pompeii, Regio VI, Insula 1." Vegetation History and Archaeobotany 22: 409-419.

Overbeck, Johannes. 1884. Pompeji in seinen Gebäuden, Alterthümern und Kunstwerken. Leipzig: Wilhelm Engelman.

Pals, Jan Peter, Vera Beemster, and Aart Noordam. 1989. "Plant remains from the Roman castellum Praetorium Agrippinae near Valkenburg (prov. of Zuid-Holland).” Archäobotanik. Dissertationes Botanicae 133: 117-134.

Patay, Árpád, and Klára Póczy. 1964. "Gyümölcsmaradványok az aquincumi múmiasírból (Obstrelicte im Mumiengrab von Aquincum).” Magy. Mezögazd. Múz. Közlem 1964: 135-147.

Pelling, Ruth, Gill Campbell, Wendy Carruthers, Kath Hunter, and Peter Marshall. 2015. "Exploring contamination (intrusion and residuality) in the archaeobotanical record: case studies from central and southern England." Vegetation History and Archaeobotany 24 (1): 85-99.

Perinić Muratović, Ljubica, and Hrvoje Vulić. 2009. "Razmatranja o Silvanovom kultu u Panoniji povodom nalaza žrtvenika u Viknovcima.” Prilozi 26: 165-180.

Petru, Sonja. 1972. Emonske nekropole (odkrite medleti 1635-1960). Katalogi in monografije 2. Ljubljana: Narodni muzej u Ljubljani.

Petrucci-Bavaud, Marianne. 1996. "Pflanzliche Speisebeigaben in den Brandgräbern." Jahresberichte aus Augst und Kaiseraugst 17:253-259 and 264-310.

Petrucci-Bavaud, Marianne, and Angela Schlumbaum. 1997. "Archäobotanische Untersuchungen der römerzeitlichen Brandbestattungen von Holzhäusern.” Tugium 13: 133-134. 
Petrucci-Bavaud, Marianne, and Stefanie Jacomet. 1997. "Zur Interpretation von Nahrungsbeigaben in römerzeitlichen Brandgräbern.” Ethnographisch-Archäologische Zeitschrift 38: 567-593.

Philpott, Robert. 1991. Burial practices in Roman Britain: A survey of grave treatment and furnishing, AD 43410. British Archaeological Report 219. Oxford: Archaeopress.

Piening U. 1986. "Verkohlte pflanzliche Beigaben aus einem frührömischen Grabhügel bei Rüchel, Kreis CochemZell." Tnerej- Zeitschrifr 49: 257-271.

Piranomonte, Marina. 2015. "The discovery of the fountain of Anna Perenna and its influence on the study of ancient magic." In The Wisdom of Thoth. Magical Texts in Ancient Mediterranean Civilisations, edited by Graŝyna Bąkowska-Czerner, Alessandro Roccati, and Agata Świerzowska, 71-85. Oxford: Archaeopress.

Pradat, Bénédict. 1994. Les offrandes alimentaires végétales dans les tombes antiques: exemples d'incinérations à Lyon et à Marseille. Paris: Université de Paris.

Preiss, Sidonie, Veronique Matterne, and Frederic Latron. 2005. "An approach to funerary rituals in the Roman provinces: plant remains from a Gallo-Roman cemetery at Faulquemont (Moselle, France)." Vegetation History and Archaeobotany 14: 362-372.

Reed, Kelly, and Tino Leleković. 2017. "First evidence of rice (Oryza cf. sativa L.) and black pepper (Piper nigrum) in Roman Mursa, Croatia." Archaeological and Anthropological Science. Advance online publication. doi: 10.1007/s12520-017-0545-y

Richmond, Ian A. and Gillam, J.P. 1951. "The Temple of Mithras at Carrawburgh." Archaeologia Aeliana (3rd series) 29: 1-92.

Robinson, Mark. 2002. "Domestic burnt offerings and sacrifices at Roman and pre-Roman Pompeii, Italy." Vegetation History and Archaeobotany 11: 93-100.

Rottoli, Mauro, and Elisabetta Castiglioni. 2011. "Plant offerings from Roman cremations in Northern Italy: a review." Vegetation History and Archaeobotany 20: 495-506.

Rüpke, Jörg, ed. 2007. The Religion of the Romans. Cambridge: Wiley-Blackwell.

Sági, Károly-Fözes, and Miklós Füzes. 1967. "Régészeti és archaeobotanikai adatok a Pannoniai kontinuitás kérdéséhez." Agrártörténeti Szemle 9: 79-91.

Schäfer, Claude. 1922. "La nécropole gallo-romaine de Stephansfeld-Brumath." Cahiers d'Archéologie et d'Histoire d'Alsace 4: 124-138.

Scheid, John. 1984. "Contraria facere: renversements et déplacements dans les rites funeraires." Archeologia e Storia Antica 6: 117-39

Scheid, John. 2007. "Sacrifices for gods and ancestors." In A companion to Roman religion, edited by Jörg Rüpke, 263-272. Cambridge: Wiley-Blackwell.

Scheid, John. 2012. "Roman animal sacrifice and the system of being." In Greek and Roman Animal Sacrifice, Ancient Victims, Modern Observers, edited by Christopher A. Faraone and F.S. Naiden, 84-92. Cambridge: Cambridge University Press.

Schroeder, Kurt. 1980/81. "Das Steinobst aus dem römischen Grabhügel von Siesbach.” Trierer Zeitschr. 43/44: 263-283.

Schultz, Celia E. 2016. "Roman Sacrifice, Inside and Out.” The Journal of Roman Studies 106: 58-76.

Simonett, Christoph. 1941. Tessiner Gräberfelder: Ausgrabungen des Archäologischen Arbeitsdienstes in Solduno, Lucarno-Muralto, Minusio und Stabio 1936 und 1937. Monographien zur Ur- und Frühgeschichte der Schweiz, 3. Basel: Birkhäuser.

Šoštarić, Renata, Marko Dizdar, Dora Kušan, Vladimir Hršak, and Sara Mareković. 2006. "Comparative Analysis of Plant Finds from Early Roman Graves in Ilok (Cuccium) and Ščitarjevo (Andautonia), Croatia - A Contribution to Understanding Burial Rites in Southern Pannonia.” Coll. Antropol. 30: 429- 436. 
Šoštarić, Renata, Hrvoje Potrebica, Jelena Hršak, and Sara Essert. 2017. "Archaeobotanical components of grave goods in prehistoric tumuli 6 and 7 at the archaeological site of Kaptol-Gradci, near Požega (Croatia)." Acta Botanica Croatica 76 (2): 183-190.

Thanheiser, Ursula, and Heinrich Zabehlicky, 1993. "Pflanzenreste aus einem kaiserzeitlichen Brandgrab in Carnuntum." In Bioarchäologie und Frühgeschichtsforschung. Berichte des Symposions der Kommission für Frühmittelalterforschung, 13-15. November 1990, Stift Zwettl, Niederösterreich Archaeologia, edited by Herwig Friesinger, Falko Daim, Erika Kanelutti, and Otto Cichocki, 101-108. Austriaca - Monographien 2. Wien: Verlag.

Toynbee, Jocelyn. 1996. Death and Burial in the Roman World. Baltimore: Johns Hopkins University Press.

Tran Tam Tinh, Vincent. 1964. Essai sur le culte d'Isis à Pompéi. Paris: Broccard.

Van der Veen, Marijke, and Glynis Jones. 2006. "A re-analysis of agricultural production and consumption: implications for understanding the British Iron Age." Vegetation History and Archaeobotany 15 (3): 217-228.

Vandorpe, Patricia, and Stefanie Jacomet. 2011. "Remains of burnt vegetable offerings in the temple area of Roman Oedenburg (Biesheim-Kunheim, Haut-Rhin, Alsace). First results.” In Carpologia. Articles réunis à la mémoire de Karen Lundström-Baudais, edited by Julian Wiethold, 87-100. Glux-en-Glenne: Bibracte.

Vulić, Hrvoje, and Anita Rapan Papeša. 2007. "Vinkovci - Ulica I. Gundulića 39." In Hrvatski arheološki godišnjak. 4, edited by Matica Blanda, 73-75. Zagreb: Ministarstvo Kulture.

Vulić, Hrvoje, and Anita Rapan Papeša. 2009. Vinkovci - Lapovačka ulica (Kaufland). In Hrvatski arheološki godišnjak. 6, edited by Zoran Wiewegh, 52-55. Zagreb: Ministarstvo Kulture.

Währen. Max. 1983. "Brot und Gebäck in einem römischen Brandgrab aus Saffig 2." Jahrhunderts n. Chr. 2: 512.

Währen, Max. 1990. "Brot und Gebäck in keltischen Gräbern und römischen Aschengruben. Identifizierung von Brot und Gebäckfunden aus dem Gräberfeld von Wederath-Belginum.” Trierer Zeitschr 53: 195-224.

Wheeler, Robert E.M., and Tessa V. Wheeler. 1936. Verulamium. A Belgic and Two Roman Cities. Oxford: Society of Antiquaries Research Report 11.

Wiethold, Julian. 1996. "Fonctionnement socio-economique de l'oppidum du $\mathrm{II}^{\circ}$ s. av. J-C au I ${ }^{\circ}$ ap. J-C. Analyse de macro-restes végétaux du Mont Beuvray." In Document Final de Synthése 1993-1995, rapport triennial edited by J-L. Flouest, 1-13. Glux-en-Glenne: Bibracte.

Wiethold, Julian. 2000. “Die Pflanzenreste aus den Aschengruben. Ergebnisse archäobotanischer Analysen.” In Archäologische Untersuchungen im Trassenverlauf der Bundesautobahn 8 im Landkreis Merzig-Wadern, edited by Andrei Miron, 131-152. Bericht der Staatlichen Denkmalpflege im Saarland, Beiheft, 4. Saarbrücken: Staatliches Konservatoramt des Saarlandes.

Wiethold, Julian. 2009. "Etude carpologique et anthracologique d'un bûcher funéraire: la structure 2 du sondage A 27 [Rapport d' etude carpologique 2009/8]." In Avallon, Les Près Damoiseau, Sur les Près au Blanc, edited by N Tisserand, A Burgevin, D Cambou, A Delor-Ahü, C Fossurier, V Lamy, P Nouvel, and J Wiethold, 68-77. Dijon: Inrap GES.

Wiethold, Julian. 2011. "Carpologia." In Actes de la table ronde de carpologues françaises, tenu à Bibracte, Centre archéologique européen, Glux-en-Glenne, 9-12 Juin 2005, 253-254. Glux-en-Glenne: Bibracte.

Wiethold, Julian. 2012. "Etude connexe 6: Etude carpologique. Agriculture et alimentation végétale d'une villa gallo-romaine et d'occupation mérovingienne à Hérange [Rapport archéobotanique 2012/13]." In Hérange, Moselle, «Weihermattfeld», LGV Est-site 4. Aménagements d'une Pars rustica, directed by E Billaudeau, 187221. Metz: Inrap Grand Est nord.

Wiethold, Julian. 2013a. "Etude carpologique et anthracologique des structures funéraires du Haut Empire." In Hageville et Saint-Julien-l es-Gorze, Meurthe-et-Moselle, Chambley Planet'Air, site 3. Developpement d'une necropole entre le haut Empire et le debut du haut Moyen-âge, edited by A Lefebvre, S Braguier, A Bressoud, 
H Cabart, M Dohr, H Guiraud, J-D Laffite, K Michel, P Pernot, F Verdelet, S Viller, and J Wiethold, 244-253. Metz: Inrap Grand Est nord.

Wiethold, Julian. 2013b. "Etude carpologique et anthracologique des structures funéraires de l'Antiquit e (fin I er-Iere moitié du IIIe s. ap. J.-C.) [Rapport archéobotanique 2013/25]." In Grostenquin, Moselle «Route de Linstroff - Lotissement Saint-Jean». Rapport d'opération. Fouille arch eologique, edited by A Lefebvre, S Braguier, A Bressoud, H Cabart, M Dohr, H Guiraud, J-D Laffite, K Michel, F Thieriot, F Verdelet, and J Wiethold, 179-196. Metz: Inrap Grand Est nord.

Wilkes, John. 1995. The Illyrians. London: Wiley-Blackwell

Willerding, Ulrich. 1978. "Die Pflanzenreste." In: Mackensen M, Das romische Graberfeld auf der Keckwiese in Kempten. Materialhcfte zur Bayerischen Vorgeschichtc 34: 183-192.

Willerding, Ulrich. 1979. "Zum Ackerbau in der jüngeren vorrömischen Eisenzeit." Archaeo-Physika 8: 309330 .

Williams, Howard. 2004. "Potted histories - cremation, ceramics and social memory in early Roman Britain." Oxford Journal of Archaeology 23(4): 417-427.

Yılmaz, Hatice, Ünal Akkemik, and Şehrazat Karagöz. 2013. "Identification of plant figures on stone statues and sarcophaguses and their symbols: the Hellenistic and Roman periods of the eastern Mediterranean basin in the Istanbul Archaeology Museum." Mediterranean Archaeology and Archaeometry 13: 135-145.

Zach, Barbara. 2002. "Vegetable offerings on the Roman sacrificial site in Mainz, Germany - Short Report on the First Results." Vegetation History and Archaeobotany 11: 101-106. 


\section{Tables}

Table 1. Plant taxa from the study sites in Croatia

Table 2. Plant taxa from Roman shrines in the Roman Empire (presence/absence data)

Table 3. Archaeobotanical data from cremations in the Roman Empire (presence/absence data) 
Table 1. Plant taxa from the study sites in Croatia

\begin{tabular}{|c|c|c|c|c|c|c|c|}
\hline Taxa: / Site: & OSDIV94 & OSDIV123 & VKFL44 & VKFL45 & VKFL43 & VIG48 & VIG39 \\
\hline Century & $2-3 r d$ & $2-3$ rd & $\begin{array}{l}\text { first half of } \\
\text { 3rd }\end{array}$ & $\begin{array}{l}\text { first half of } \\
\text { 3rd }\end{array}$ & 4 th & 4 th & 4 th \\
\hline Context & Cremation & Cremation & Cremation & Cremation & Inhumation & Inhumation & Altar \\
\hline \multicolumn{8}{|l|}{ Cereals } \\
\hline Hordeum vulgare & & & & & 1 & 2 & 7 \\
\hline Triticum aestivum/durum & & & & & & & 2 \\
\hline Triticum spelta & & & & & & 1 & \\
\hline Panicum miliaceum & & & 1 & 2 & & & 2 \\
\hline cf. Panicum sp. & & & & 1 & & & \\
\hline Cereal indet & 5 & 1 & & 1 & 1 & 2 & 7 \\
\hline \multicolumn{8}{|l|}{ Oil crops } \\
\hline Linum usitatissimum & & & & & & 1 & \\
\hline \multicolumn{8}{|l|}{ Pulses } \\
\hline Lens culinaris & 7 & & 1 & 1 & & & \\
\hline Lathyrus sativus & & & 2 & & & & \\
\hline Indet pulse & & 1 & 5 & 2 & 2 & & 1 \\
\hline \multicolumn{8}{|l|}{ Wild/Weed } \\
\hline Agrostemma githago & & & & & & 1 & \\
\hline Avena sp. & & & & & & 3 & 1 \\
\hline Bromus sp. & & & & & & 1 & 1 \\
\hline Carex cf. spicata & & & & & & 3 & \\
\hline Carex sp. & & & & & & 4 & \\
\hline Chenopodium sp. & & & & & & 1 & \\
\hline Eleocharis palustris & & & & & & 1 & \\
\hline Galium sp. & & & & & & 1 & 1 \\
\hline Gramineae & & & & & & 3 & \\
\hline Lamiaceae & & & & & & 1 & \\
\hline Lolium sp. & & & & & & 1 & \\
\hline Medicago sativa & & & & & & 1 & \\
\hline cf. Mentha sp. & & & & & & 5 & \\
\hline Ononis spinosa & & & & & & 1 & \\
\hline Poa sp. & & & & & & 3 & \\
\hline Polygonum sp. & & & 1 & 1 & & & \\
\hline Rumex sp. & & & & & & 1 & \\
\hline Sambucus ebulus & & & 1 & & & & \\
\hline Scirpus cf. lacustris & & & & & & 1 & \\
\hline Scirpus sp. & & & & & & 1 & \\
\hline Trifolium sp. & & & & & & 2 & 1 \\
\hline Verbascum sp. & & & & & & 1 & \\
\hline Amorphous food remains & & & 31 & 1 & & & \\
\hline Indet & 24 & 1 & 1 & 8 & 25 & 17 & 29 \\
\hline Total identified seeds & 12 & 2 & 11 & 8 & 4 & 42 & 23 \\
\hline Seed density & 1.2 & 0.2 & 1.1 & 0.8 & 0.4 & 4.2 & 2.3 \\
\hline
\end{tabular}


